\title{
Understanding the Role and Constraints of Rice-based Agriculture for Improving Rural Livelihoods in North-Eastern Region of India
}

\author{
Aldas Janaiah* \\ Professor and University Head, Department of Agricultural Economics, \\ College of Agriculture, PJTSAU, Rajendranagar, Hyderabad-500 030, India \\ *Corresponding author
}

\section{Keywords}

Rice, North-east region, Food and nutritional security

Article Info

Accepted:

20 May 2020

Available Online:

10 June 2020

\section{A B S T R A C T}

The rice-based agriculture is a key source of livelihood for about 40 million people in North-East Region (NER). But crop yields are very low much below the national average.. This paper examines the the importance of rice-based food system and its growth performance, bring out constraints and suggest a roadmap to improve livelihoods of about 40 million people of NER. Series of secondary data on rice and other food products for the past fifteen years for each state of NER were collected from published and unpublished reports, and same were analysed using regression for estimation of compound growth rates. There has been considerable increase in food grain production from about 6 to 8.1 million tonnes over the past fifteen years due to special efforts by However Union Government after 2004 to improve livelihoods of rural households in NER. But the NER continues to be in food deficit by about half million tonnes per year. Low crop yields, despite high rainfall and fertile soils, is the primary reason for food insecurity in the region. Further, lack of adequate value addition and market access, high levels of illiteracy, poor infrastructure, etc. are some more reasons why low-income levels persist in the region, and thereby food and nutritional insecurity. Without improving productivity and income from rice-based agri-food systems, improved household food and nutritional security cannot be achieved in NER. Major constraints to increasing farm productivity and, thereby, incomes of rice-farming households include: lack of a wide range of varietal choice suitable for diverse production environments for rice and pulses/vegetables, very low seed replacement rate (ca. 12\%), poor water management and poor drainage systems, low fertilizer use (less than $20 \mathrm{~kg} / \mathrm{ha}$ ), unwillingness to take up rice in the second season due to perceived losses from animal grazing, absence of electricity in many rural areas of NER for pumping groundwater in the dry season, lack of marketing systems to purchase any marketable surplus at affordable price, absence of post-harvest loss management, lack of farmer-acceptable farm machinery, and increase wage rates of farm laborers. Based on critical analysis of growth performance, and potential opportnities and challenges, a 3pronged strategy is suggested in the paper for improving productivity and nutritional quality of rice-based agri-food systems in the NER. 


\section{Introduction}

The North-East Region of India (NER) comprises of eight states viz., Assam, Arunachal Pradesh, Meghalaya, Manipur, Mizoram, Nagaland, Sikkim and Tripura. The NER less Assam is considered to be the North-Eastern Hill Region (NEHR), as it is predominantly a hill area. The NER has geographically, demographically, culturally, socially, economically and politically distinct features. This region is geographically dominated by hill areas and ethnic tribes who play a key role in its economy and is driven by a rice-based agriculture system. Total geographical area of the region is 262,180 $\mathrm{km}^{2}$ which is about $8 \%$ of the country's total area, sheltering about $4 \%$ of total India's population. The net sown area is highest in Assam (34\%) where plains account for $84 \%$ of its total geographical area, followed by Tripura (24\%), while Arunachal Pradesh has lowest net sown area (only 2\%).. The demographic and socio-economic features of NER are distinct from the rest of India. About $80 \%$ of NER's population lives in rural areas, depending on rice-based agriculture as the key source of livelihood. Further, local ethnic tribes with diverse cultural background account for two-thirds of the population in NEHR (North East Council, 2018). The tribal population in NEHR's states of Arunachal Pradesh, Manipur, Meghalaya, Mizoram, Nagaland, Sikkim and Tripura is $9.52(69 \%)$, 9.0 (36\%), 25.55 (86\%), 10.34 (94\%), $17.186 \%), 2.06(40 \%)$ and $11.66(32 \%)$ lakhs respectively North East Council, (2017). Jhum cultivation is a common practice in hill areas of NER. Nearly half million tribal farm families belonging to 38 major ethnic tribes practice Jhum cultivation in 35 districts of NER especially in hill region, as a part of tribes' traditional practice, covering about 2.5 million ha (Nagachan et al., (undated). However, rice productivity under Jhum lands is very low (about 1 ton / ha). Further, out of
4 million ha of net cultivated area in NER, one-third suffers from serious soil erosion and degradation problems mainly due to widespread practice of Jhum or shifting cultivation by tribal communities and because of the topography of the land (Bujarbaruah, 2004).

Food insecurity and malnutrition are serious problems in the NER. The per capita food grain intake (grams/day) in Manipur, Meghalaya, and Mizoram was 344, 321 and 157, which are lower than the national average of 444 grams/day. Average calorie intake in Manipur, Meghalaya, and Mizoram are 1952, 1701 and 1968 Kcal/day respectively, which are lower than the India's average of $2123 \mathrm{Kcal} /$ day (Giribabu, 2013). Half of the children in the region suffer from malnutrition. One of the important reasons for the high incidence of malnutrition among the productive age groups is low income from rice based agriculture thereby nonaccessibility of healthy foods due to poor economic and institutional factors.

Per capita income of people in NER is about 20 to $40 \%$ lower than the national average except in Sikkim. The per capita income (current prices) of people in Manipur, Meghalaya, Nagaland and Tripura was INR 55603, 71318, 83621 and 80027 respectively against national average of INR 94473 during 2015-16 (CSO, 2018). Low income from the principal crop of rice is one of the main reasons for low per capita income in many NEHR's states. Although rice occupies $85 \%$ of cropped area in NEHR, its share in household income is less than $10 \%$ mainly due to subsistence nature of rice farming with low productivity and lack of market facilities. Low income level and non-availability of adequate quantity of food grains are main reason for food insecurity and malnutrition in the region. NER as a whole has a food deficit of about 8 to $10 \%$ (Roy, et al., 2015). Thus, 
improving productivity and income of farm households is key to addressing these issues.

The agricultural production system of NER is characterized by many and diverse risks such as: poor water management, subsistence farming, undulating topography and inappropriate land-use patterns with annual loss of top soil of $46 \mathrm{t} / \mathrm{ha}$. Fertilizer use in the region is very low with only about $15 \mathrm{~kg} / \mathrm{ha}$. In addition, chemical pesticides-use is also meager $(0.16 \mathrm{~g} / \mathrm{ha})$. As a result, crop yields are far below the national average.

The agro-biophysical, and socioeconomic profile of NER, especially NEHR clearly indicate the need for improving productivity in order to address the food and nutritional security in the region. The Government of India has recognized this fact and has a special focus on development of the NER and set up a separate Ministry of Development of NER (MDONER) in 2003. Since then, several special agriculture development and livestock development programmes have been initiated in the region. Various stakeholders and institutions of both Central and State governments such as Indian Council of Agricultural Research (ICAR), Central Agricultural University (CAU), state departments of agriculture and livestock of NER states, Ministry of Agriculture of Government of India, MDONER, etc. have been actively engaged in the development of agriculture and livestock in the region since early 2000s.

Substantial funding was allocated by the Ministry of Agriculture, Cooperation and Farmers Welfare under Rashtriya Krishi Vigyan Yojana (RKVY) to NEHR from 201011 onwards. Further, about a quarter of the total funds allocated to North East Council (NEC) were devoted to the development of agriculture and allied sectors in NER in 11 and $12^{\text {th }}$ Five-Year Plan periods. NEC alone invested about INR 400 crore (\$ 61.5 million) during 2016-17 for agriculture and allied sectors in the region (NEC, 2018). With the increased flow of funding to NER over the past 12 to 15 years, ICAR in collaboration with State Departments of agriculture and other stakeholders have initiated several new development programmes in the region. A special rice development scheme, special pulses promotion schemes, a seed promotion scheme, a HYV promotion scheme, a watershed development scheme, a soil health management scheme, a special fisheries development scheme, promotion of organic farming, a special skilled development scheme, etc. are some of the important initiatives undertaken by various State governments with technical support from ICAR in the NER. As a result, the productivity of agriculture and livestock improved substantially after 2000. Nevertheless, despite these initiatives productivity remains far behind national levels.

With this background of socioeconomic, cultural and biophysical features of NER, an attempt has been made to assess the recent growth performance of agriculture and livestock sectors in order to understand future development options across the NER, and to identify new opportunities to improve ricebased agri-food systems in the region.

\section{Materials and Methods}

Time series and cross section data related to area, production and yield of major crops were collected from published reports of Ministry of Agriculture and Farmers' Welfare and North East Council, Government of India. Similarly secondary data on livestock products for NER states were collected from the same source. Apart from tabular analysis, annual compound growth rates were estimated for various crops and livestock products by fitting a log linear regression model. 


\section{Results and Discussion}

\section{Trends in area, production and yield of major crops}

The changes in area, production and yield of major food crops in NER during 2001-2016 were computed and documented in tables 1 and 2. About $80 \%$ of people depend on ricebased agri-food systems for their livelihood in NER. Rice accounts of nearly $85 \%$ of cropped area in the region. The share of rice in total food grains (cereals, millets and pulses) is about $90 \%$, and its share in total cereals is $95 \%$ (Table 1). Therefore, food and nutritional security of the people in NER cannot be achieved without increasing productivity and profitability of rice-based households. Thus all stakeholders-both central and state governments' institutions and development organizations-have focused on the improvement of rice-based agriculture.

Total food grain and rice production has increased significantly by 30 to $35 \%$ between triennium ending 2003 and 2016, without an increase in area under these crops during the same period (Table 1). Further, the production of other key food items such as pulses, fruits and vegetables have increased manifold during the same period in the region. The promotion of pulse and vegetable crops as second crop after rice crop, as well as yield improvement of these high-nutritive food crops has been given special emphasis during this period. There has been significant increase in rice yields as well during this period, which is key source of incremental increase in rice production during the period (Table 2).

\section{Trends in livestock products}

Livestock plays a key role not only as a source of household income, but also as an important component of food and nutrional security in NER. The production of livestockbased food items has also significantly increased over the past 15 years in the region. In particular, meat and milk production has nearly doubled in the region during the period (Table 3). This is a sign of improvement in food and nutritional security of rural households in NER in the recent past of 15 years. The improvements in livestock products may be attributed to special focus given in the region after creation of Ministry of NER in 2003.

\section{Growth performance-state wise analysis}

A semi-log linear regression is fitted to estimate annual compound growth rates for total food grains as a whole and also for rice as well by each state of NER. The growth performance was analysed separately for two periods viz., 2001-02 to 2009-10 and 2010-11 to 2015-16 to examine changes in growth between two periods. State-wise performance of the growth trends in total food grains and rice (Tables 4 and 5) indicate that the recent past five-year period 2010-11 to 2015-2016 registered a higher growth than in the previous ten years 2001-02 to 2009-2010. In the case of rice, productivity increase was almost stagnant in the region between 200102 to $2009-10$ but increased significantly at the rate of ca. $4 \%$ per year during the period 2010-11 to 2015-16 (Table 5). The increase in production and productivity of food grains and rice was achieved through adoption of high-yielding varieties, quality seed materials and timely supply of improved seeds as part of special programmes mentioned above.

Although large number of local landraces of rice are widely grown, and these are welladapted to the agro-climatic conditions of NER, some HYVs such as Kalinga 11, Neela, Hira, Annada, Govinda, Tara, Subhadra, etc. were released in the NER under special rice development programmes. Most of these 
HYVs were developed in Assam and by ICAR for NEHR. Despite these successes, HYV adoption rate is very limited in NER because consumers prefer mainly local rice varieties which are sticky as well as having higher nutritional value e.g. black rice variety from Manipur. Therefore, there is a potential opportunity to develop HYVs based on local rice varieties, with shorter duration suitable for direct seeding under hill and terrace farming conditions and with consumerpreferred traits to improve rice productivity in the region.

At present, rice production in NER is about 7.2 million tonnes, which is about $7 \%$ of India's total rice production and its share in rice area is $8.5 \%$. Assam accounts for nearly two-thirds of the total area and production of food grains of region. Thus, rice area and production in seven states of NE Hill Region (other than Assam in NER) was only 1.5 million ha and 2.2 million tonnes respectively in 2015-16 (Government of India, 2017). Therefore, excluding Assam, the share of NEHR in India's rice area and production is about $3.5 \%$ and $2.1 \%$ respectively. The average rice yield in NEHR is only half of the national average.

Despite substantial increase in rice as well as other food items over the past 15 years, NER is still in food deficit for many food items. For instance, the rice production is in deficit by nearly $10 \%$ to meet its consumption requirements (Roy et al., 2015). Widespread absolute poverty, malnutrition among young children, low income, low crop productivity and profitability, Jhum cultivation, etc. remain major socio-economic issues, which need more attention. Low seed replacement rate, lack of locally adaptable HYVs, low skills of human resources, soil and water management problems, etc. are still unsolved problems in the region. Crop productivity in the jhum lands is still at low. The socioeconomic capacity of about half million tribal families is directly linked with jhum cultivation in NEHR. There is a huge potential to develop a modern value chain for farm produce from jhum cultivation as it is very close to being "organic" and could be marketed as such.

\section{Constraints and Challenges}

Despite substantial progress made in NER's agricultural development in the recent past, agriculture in the NEHR remains very inefficient and does not meet the food security and nutritional needs of its people. The following constraints may be considered as development barriers in the region (ICARCNEHR, 2018)

Lack of acceptance of new HYV rice cultivars developed by Assam Agricultural University and ICAR in NEHR.

Lack of coherence between different programmes on agriculture and across states of NEHR

Low private sector and NGOs participation in programmes.

Very limited participation of international R\&D institutions e.g. IRRI

Above issues largely constrain the North-East Hill Region (other than Assam) to achieve self-sufficiency in foodgrains. The NEHR produces only $1.2 \%$ of national food grain production and continues to be a net importer of food grains for its own consumption. The productivity of land as compared to its potential is low, only half of India's average food grain yield. Low per capita income, low per capita food grain intake, low calorie intake, malnutrition among productive age groups, large scale practice of jhum farming in the hill regions, etc. are major challenges. 
Table.1 Changes in area and production of various food crops between 2001-03 and 2014-16 in North Eastern Region of India

\begin{tabular}{|c|c|c|c|c|c|c|}
\hline \multirow[t]{2}{*}{ Items } & \multicolumn{3}{|c|}{ Area (000 ha) } & \multicolumn{3}{|c|}{ Production (000 tonnes) } \\
\hline & $2001-03$ & 2014-16 & $\%$ change & $2001-03$ & 2014-16 & $\%$ change \\
\hline Foodgrains & 3931.4 & 4006.6 & 1.9 & 5987.7 & 8124.9 & 35.7 \\
\hline Cereals & 3718.4 & 3714.6 & -0.1 & 5866.8 & 7719.4 & 31.6 \\
\hline Rice & 3437.7 & 3448.4 & 0.3 & 5463.3 & 7225.4 & 32.3 \\
\hline Pulses & 179.8 & 252.1 & 40.3 & 118.2 & 217.7 & 84.2 \\
\hline Fruits & 271.2 & 499.0 & 84.0 & 1948.8 & 4959.9 & 154.5 \\
\hline Vegetables & 127.7 & 548.7 & 329.7 & 1364.8 & 6552.6 & 380.1 \\
\hline
\end{tabular}

Source: Compiled from Agriculture Statistics at a Glance (various issues), Ministry of Agriculture and Farmers' Welfare, Government of India, New Delhi

Table.2 Changes in yield of various products between 2001-03 and 2014-16 in North Eastern Region of India

\begin{tabular}{|l|c|c|c|}
\hline Items & Yield (t/ha) & & \\
\hline Foodgrains & $2001-2003$ & $2014-2016$ & $\%$ change \\
\hline Cereals & 1.5 & 2.0 & 33.1 \\
\hline Rice & 1.6 & 2.1 & 31.7 \\
\hline Pulses & 1.6 & 2.1 & 31.8 \\
\hline Fruits & 1.0 & 0.9 & -12.4 \\
\hline Vegetables & 7.2 & 9.9 & 38.7 \\
\hline
\end{tabular}

Source: Compiled from Agriculture Statistics at a Glance (various issues), Ministry of Agriculture and Farmers' Welfare, Government of India, New Delhi

Table.3 C: Changes in production of various livestock products between 2001-03 and 2014-16 in North Eastern Region of India

(000 tons)

\begin{tabular}{|l|c|c|c|}
\hline Items & $\mathbf{2 0 0 1 - 2 0 0 3}$ & $\mathbf{2 0 1 4 - 2 0 1 6}$ & \% change \\
\hline Fish & 224.4 & 278.7 & 24.2 \\
\hline Egg & 873.5 & 1024.9 & 17.3 \\
\hline Milk & 118.4 & 232.0 & 95.9 \\
\hline Meat & 118.4 & 232.0 & 95.9 \\
\hline
\end{tabular}

Source: Compiled from Agriculture Statistics at a Glance (various issues), Ministry of Agriculture and Farmers' Welfare, Government of India, New Delhi 
Table.4 Growth performance of total food grains in NE States, India (2001-02 to 2015=16) (Compound annual rate of increase-\%/year)

\begin{tabular}{|c|c|c|c|c|c|c|c|c|c|}
\hline \multirow[t]{2}{*}{ States } & \multicolumn{3}{|c|}{ 2001-02 to 2009-10 } & \multicolumn{3}{|c|}{$2010-11$ to $2014-15$} & \multicolumn{3}{|c|}{$2001-02$ to $2014-15$} \\
\hline & $\mathbf{A}$ & $\mathbf{P}$ & $\mathbf{Y}$ & $\mathbf{A}$ & $\mathbf{P}$ & $\mathbf{Y}$ & $\mathbf{A}$ & $\mathbf{P}$ & $\mathbf{Y}$ \\
\hline $\begin{array}{l}\text { Arunachal } \\
\text { Pradesh }\end{array}$ & $0.85 * * *$ & $2.00 * *$ & $1.15^{*}$ & $1.55 * * *$ & $6.21 * * *$ & $4.64 * * *$ & $0.79 * * *$ & $5.16 * * *$ & $4.36 * * *$ \\
\hline Assam & $-1.08 *$ & $-0.74^{\mathrm{NS}}$ & $0.28^{\mathrm{NS}}$ & $-0.27 *$ & $3.67 * * *$ & $3.98 * * *$ & $0.30 *$ & $3.80 * * *$ & $3.50 * * *$ \\
\hline Manipur & $1.84 * * *$ & $0.61^{\mathrm{NS}}$ & $-1.19 * *$ & $2.96 * *$ & $-2.09^{\mathrm{NS}}$ & $-4.42 *$ & $4.14 * * *$ & $2.27 * *$ & $-1.89 * * *$ \\
\hline Meghalaya & $-0.55^{*}$ & $0.49^{\mathrm{NS}}$ & $1.05^{*}$ & $0.50 * *$ & $6.83 * * *$ & $6.29 * * *$ & $0.07^{\mathrm{NS}}$ & $2.54 * * *$ & $2.47 * * *$ \\
\hline Mizoram & $-1.37 * *$ & $-21.08 * * *$ & $-19.62 * * *$ & $-11.06 * * *$ & $-0.57^{\mathrm{NS}}$ & $10.81 * * *$ & $-5.83 * * *$ & $-8.06 * * *$ & $-1.90^{\mathrm{NS}}$ \\
\hline Nagaland & $2.37 * * *$ & $2.93 * * *$ & $0.48 *$ & $2.43 * * *$ & $7.60 * * *$ & $5.41 * * *$ & $1.66 * * *$ & $4.25 * * *$ & $2.53 * * *$ \\
\hline Sikkim & $1.54 * * *$ & $1.93 * * *$ & $4.99 * * *$ & $-4.28 * * *$ & $-2.11 * * *$ & $2.15 * * *$ & $-0.65^{*}$ & $0.66 * *$ & $3.45 * * *$ \\
\hline Tripura & $-0.39 * *$ & $2.20 * * *$ & $7.51 * * *$ & $0.88 *$ & $2.50 * * *$ & $1.63 * * *$ & $0.63 * * *$ & $2.79 * * *$ & $4.33 * * *$ \\
\hline NE Region & -0.49 & -0.15 & 0.31 & 0.11 & $3.61 * *$ & $3.54 * *$ & $0.54 *$ & $3.44 * * *$ & $2.9 * * *$ \\
\hline
\end{tabular}

Source: Own estimates-based data compiled from Agriculture Statistics at a Glance (various issues), Ministry of Agriculture and Farmers' Welfare, Government of India, New Delhi A-area, P-Production, Y-Yield *means significant at 10 per cent, ** means significant at 5 per cent, *** means significant at 1 per cent significance level

Table.5 Growth performance of rice in NE States, India (200-2016)

(Compound annual rate of increase-\%/year)

\begin{tabular}{|c|c|c|c|c|c|c|c|c|c|}
\hline \multirow[t]{2}{*}{ States } & \multicolumn{3}{|c|}{$2001-02$ to $2009-10$} & \multicolumn{3}{|c|}{$2010-11$ to $2015-16$} & \multicolumn{3}{|c|}{$2001-02$ to $2015-16$} \\
\hline & $\mathbf{A}$ & $\mathbf{P}$ & $\mathbf{Y}$ & $\mathbf{A}$ & $\mathbf{P}$ & $\mathbf{Y}$ & $\mathbf{A}$ & $\mathbf{P}$ & $\mathbf{Y}$ \\
\hline $\begin{array}{l}\text { Arunachal } \\
\text { Pradesh }\end{array}$ & $0.39 * * *$ & $2.55 * * *$ & $2.19 * *$ & $1.15 * * *$ & $4.66 * *$ & $3.41 * *$ & $0.48 * * *$ & $6.40 * * *$ & $5.93 * * *$ \\
\hline Assam & $-0.63 * *$ & $0.32^{\mathrm{NS}}$ & $1.07 * * *$ & $-0.47 * *$ & $4.03 * * *$ & $3.68 * * *$ & $0.10^{\mathrm{NS}}$ & $3.12 * * *$ & $3.11 * * *$ \\
\hline Manipur & $1.12 * *$ & $0.37^{\mathrm{NS}}$ & $-0.75^{*}$ & $2.63^{*}$ & $-5.51 * *$ & $-7.57 * *$ & $2.45 * * *$ & $0.02^{\mathrm{NS}}$ & $-2.40 * * *$ \\
\hline Meghalaya & $-0.43^{*}$ & $0.78^{\mathrm{NS}}$ & $1.21 *$ & $0.42 * * *$ & $7.30 * * *$ & $6.92 * * *$ & $0.18^{*}$ & $3.28 * * *$ & $3.09 * * *$ \\
\hline Mizoram & $-1.84 * * *$ & $-24.11 * * *$ & $-21.96 * * *$ & $-6.03 *$ & $4.57 * *$ & $10.56 * *$ & $-5.76 * * *$ & $-6.56 * *$ & $-0.26^{\mathrm{NS}}$ \\
\hline Nagaland & $2.11 * * *$ & $3.92 * * *$ & $1.77 * * *$ & $2.22 * * *$ & $5.39 * *$ & $3.30 * *$ & $2.07 * * *$ & $5.20 * * *$ & $3.12 * * *$ \\
\hline Sikkim & $-1.34 * * *$ & $1.13 * * *$ & $2.04 * * *$ & $-3.47 * * *$ & $-3.74 * * *$ & $-0.40^{\mathrm{NS}}$ & $-3.01 * * *$ & $-0.78 * *$ & $2.03 * * *$ \\
\hline Tripura & $-0.24^{*}$ & $2.32 * * *$ & $2.57 * * *$ & $0.37^{\mathrm{NS}}$ & $2.39 * * *$ & $2.00 * * *$ & $0.61 * * *$ & $2.80 * * *$ & $2.19 * * *$ \\
\hline NE region & $-0.37 *$ & $0.51^{\mathrm{NS}}$ & $0.85^{*}$ & $-0.06^{N S}$ & $3.50 * *$ & $3.56 * *$ & 0.29* & $2.98 * * *$ & $2.69 * * *$ \\
\hline
\end{tabular}

Note: Same as in Table 4 
Rice is a key source of livelihood accounting for about $80 \%$ of NEHR's cropped area, but its share of the household income is very low (less than 10\%). The subsistence nature of rice-based farming with traditional landraces and low inputs, traditional seed systems, and very little value addition to rice from jhum lands, low marketing facilities etc. are just some of the reasons for the low share of rice in household income in NEHR. Thus, the socioeconomic lives of the people of NEHR cannot be improved without enhancing the productivity and profitability of rice-based agriculture in the region. Rice yield in NEHR is only 1.5 tonne/ha, against the Assam's rice yield of 2.2 tonnes/ha.

Some of the key challenges facing rice-based agriculture in NEHR are as follows.

Rainfall-dependent rice-based farming system: Nearly $95 \%$ of the rice area in NEHR is cultivated only in the wet season under rainfed condition. Since the region is a high rainfall zone, farmers grow rice only in the kharif season. Farmers usually do not grow rice in the dry season due to lack of assured irrigation. Irrigation covers only 5-6\% of cropped area in NER.

Lack of varietal choice: Availability of suitable varieties for diverse production environments, both for rice and pulses/vegetable crops. Most of the crop varieties accessible to NEHR are developed by Assam Agricultural University (AAU) or ICAR, which mostly suitable for plain and low altitude areas, but not for hill and highaltitude areas of NEHR. Thus, the adoption of HYVs in NEHR is only $15 \%$ of the total rice area.

Very low seed replacement rate: Seed system in NEHR is informal and yet to be institutionalized. Thus, seed replacement rate in many crops is less than $10 \%$.
Poor water management, and poor drainage systems: One of the reasons for nonavailability of water for dry season is lack of rain-water management system besides poor drainage facilities.

Low fertilizer use (less than $20 \mathrm{~kg} / \mathrm{ha}$ ).

Absence of electricity in many areas of NEHR for pumping groundwater in the dry season

Lack of marketing system to sell marketable surplus: Very low market price for rice (INR 1000 / quintal against MSP of INR 1590/q). Thus, lack of financial incentives to produce more rice (and other crops).

Absence of value addition and post loss management

Lack of farmer-acceptable farm machinery for hill and high-altitude conditions.

Lack of skills and human resources capacity at various levels.

Nearly 500,000 families practice Jhum or shifting cultivation covering about 1.67 million ha of which $17 \%$ is jhumed at any point of time.

\section{Potential opportunities for value addition}

The specialty types of rice from NER (e.g. red rice and black rice) have potentially huge export potential. Further majority of food products including rice are produced with no or little chemical inputs. The NEC-vision 2020 has identified organic farming as one of the priorities in NER. In particular, modern value chain development for organic rice and special-rice, black rice, has great potential to enhance farmers' income in Manipur. Thus, there are enormous potential opportunities to increase productivity and income of rice 
farming households in NEHR, if some of above challenges are addressed through an innovative R\&D strategy coupled with policy support and institutional mechanism.

Summary and conclusion are as follows:

The rice-based agriculture is a key source of livelihood for about 40 million people in North-East Region (NER). The agricultural production system is characterized by poor water management, subsistence farming, undulating topography and poor land-use patterns. The fertilizer application is only about $15 \mathrm{~kg} / \mathrm{ha}$ and pesticides use is also meager $(0.16 \mathrm{~g} / \mathrm{ha})$. Thus, crop yields are very low. However Union Government has invested substantial resources after 2004 to improve livelihoods of rural households through enhanced crop and livestock productivity in NER.

Although there has been considerable increase in food grain production from about 6 to 8.1 million tonnes over the past fifteen years, the NER continues to be in food deficit by about half million tonnes per year. Low crop yields, despite high rainfall and fertile soils, is the primary reason for food insecurity in the region. Further, lack of adequate value addition and market access, high levels of illiteracy, poor infrastructure, etc. are some more reasons why low-income levels persist in the region, and thereby food and nutritional insecurity.

Without improving productivity and income from rice-based agri-food systems, improved household food and nutritional security cannot be achieved in NER. Therefore, it is essential to understand the technological, institutional, social and policy constraints in the region, so that an appropriate strategy can be developed to address inadequate food and nutritional security.
Major constraints to increasing farm productivity and, thereby, incomes of ricefarming households include: lack of a wide range of varietal choice suitable for diverse production environments for rice and pulses/vegetables, very low seed replacement rate (ca. 12\%), poor water management and poor drainage systems, low fertilizer use (less than $20 \mathrm{~kg} / \mathrm{ha}$ ), unwillingness to take up rice in the second season due to perceived losses from animal grazing, absence of electricity in many rural areas of NER for pumping groundwater in the dry season, lack of marketing systems to purchase any marketable surplus at affordable price, absence of post-harvest loss management, lack of farmer-acceptable farm machinery, and increase wage rates of farm laborers.

\section{A 3-pronged Roadmap to NER}

Based on critical analysis of growth performance, and potential opportunities and challenges, a 3-strategy is suggested for improving productivity and nutritional quality of rice-based agri-food systems in the NER.

Identification, adaptive evaluation, and scaling-up of a suite of technologies for NER rice-based agri-food systems (new HYVs, improved seed systems, integrated crop and resource management, farm mechanization, post-harvest loss management, optimized crop calendar, optimized water management etc.) - short term

Development of rice grain quality benchmarks for the NER and dissemination of new nutritious rice varieties with high iron and zinc content, as well as low glycemic index (GI). Identification of promising heirloom rice varieties; understanding the rice value chain and development of marketing strategies that return value to farmers 
Development of the next generation of farm extension workers, scientists, and leaders in the farm sector through a series of tailored courses that combine long-term research scholarships, medium-term on-the-job training programs, and short-term workshops and seminars

A holistic and partnership approach is needed to for NER. The livelihoods of rural people including ethnic groups can be improved not only by the enhancement of productivity and profitability of rice crop, but also by increasing the productivity thereby income from non-rice farm sources such as vegetables, maize, livestock, fisheries, value addition etc. Therefore, a multi-institutional and multi-stakeholders network with concerned institutions such as International Rice Research Institute, ICAR, CSIR, state departments of agriculture and state-owned universities, NGOs, selected private sector, etc. is needed to implement suggested roadmap in NER.

\section{Acknowledgement}

This paper is drawn from a report of the study conducted by the author at IRRI during 2017 18. Author is grateful to Dr Nafees Miah, South Asia Representative, IRRI for his assistance for the study

\section{References}

Bujarbaruah, K.M. (2004) Organic Farming: Opportunities and Challenges in North
Eastern States. ICAR Research Complex for NEH Region, Umiam, Meghalaya.

Central Statistical Organisation-CSO (2018): Statistical Report on States' Economy-2018, Central Statistical Organisation, Government of India, New Delhi

Giribabu, M (2013): Food and nutritional security in North-East India: Some contemporary issue, International Journal of Development Research, Vol. 2 (5)

Government of India (2017), Agriculture Statistics at a Glance-2017, Directorate of Economics and Statistics, Ministry of Agriculture and Farmers' Welfare, New Delhi

Government of India (2017), Agriculture Statistics at a Glance (various issues), Directorate of Economics and Statistics, Ministry of Agriculture and Farmers' Welfare, New Delhi

Indian Council of Agricultural Research Complex for NEHR (2018), Action Taken Report on Recommendations of the 23rd Regional Committee Meeting, ICAR Complex for NEHR, Barapani.

Ngachan S.V.M., A.K. Mohanty and A. Pattanayak (undated), Status paper on rice in North Eastern Region, ICAR Research Complex for NEHR, Barapani, Shilong.

North East Council-NEC (2017): Basic Statistics of North Eastern Region-2015, North East Council, Government of India, Shilong.

North East Council-NEC (2018), Vision 2020 Plan for NERs; Development, North East Council, Government of India, Shilong.

Roy A, N.U. Singh, D.S. Dkhar, A.K. Mohanty, S.B. Singh and A.K. Tripathi (2015): Food Security in North-East Region of India-A State-wise Analysis, Agricultural Economics Research Review, Vol. 28 (Conference Issue).

\section{How to cite this article:}

Aldas Janaiah. 2020. Understanding the Role and Constraints of Rice-based Agriculture for Improving Rural Livelihoods in North-Eastern Region of India. Int.J.Curr.Microbiol.App.Sci. 9(06): 2705-2714. doi: https://doi.org/10.20546/ijcmas.2020.906.328 